\title{
Association study between herpes zoster reporting and mRNA COVID-19 vaccines (BNT162b2 and mRNA-1273)
}

\author{
Laure-Hélène Préta ${ }^{1}$, Adrien Contejean ${ }^{1}$, Francesco Salvo ${ }^{2}$, Jean-Marc Tréluyer ${ }^{3}$, Caroline \\ Charlier $^{1}$, and Laurent Chouchana ${ }^{4}$ \\ ${ }^{1}$ Assistance Publique - Hopitaux de Paris \\ ${ }^{2}$ Université de Bordeaux \\ ${ }^{3}$ Affiliation not available \\ ${ }^{4}$ Hospital Cochin
}

December 15, 2021

\begin{abstract}
Several cases of herpes zoster (HZ) following mRNA COVID-19 vaccination (BNT162b2 and mRNA-1273) have been reported, and first epidemiological evidences suggest an increased risk. We used the worldwide pharmacovigilance database VigiBase to describe HZ cases following mRNA COVID-19 vaccination. We performed disproportionality analyses (case/non-case statistical approach) to assess the relative risk of HZ reporting in mRNA COVID-19 vaccine recipients compared to influenza vaccine recipients and according to patient age. Until 30th June 2021, of 716,928 reports about mRNA COVID-19 vaccines, we found $7,728 \mathrm{HZ}$ cases. When compared to influenza vaccines, mRNA COVID-19 vaccines were associated with a significantly higher reporting of HZ (reporting odds-ratio 1.9, 95\% CI [1.8-2.1]). Furthermore, we found a reduced risk of reporting HZ among under 40 year-old persons compared to older persons (reporting odds-ratio 0.39, 95\% CI [0.36-0.41]). For the first time, we could assess at a global level the risk of HZ after mRNA COVID-19 vaccination.
\end{abstract}

\section{Hosted file}

Manuscript_final_BJCP.docx available at https://authorea.com/users/451311/articles/549513association-study-between-herpes-zoster-reporting-and-mrna-covid-19-vaccines-bnt162b2and-mrna-1273

\section{Hosted file}

Table 1.docx available at https://authorea.com/users/451311/articles/549513-associationstudy-between-herpes-zoster-reporting-and-mrna-covid-19-vaccines-bnt162b2-and-mrna-1273

\section{Hosted file}

Table 2.docx available at https://authorea.com/users/451311/articles/549513-associationstudy-between-herpes-zoster-reporting-and-mrna-covid-19-vaccines-bnt162b2-and-mrna-1273 